\section{Interventionist classroom management and learning of children with disabilities in primary schools: An inclusive and reframing approach}

\author{
Musa, Matovu \\ Islamic University in Uganda, Uganda (m.matovu@iuiu.ac.ug)
}

Aidah, Nakayiza

Islamic University in Uganda, Uganda

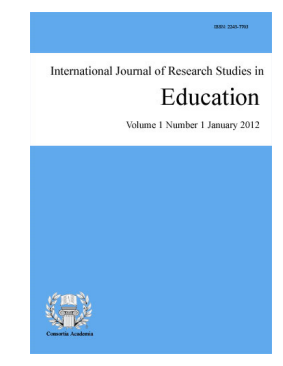

ISSN: $2243-7703$ Online ISSN: 2243-7711

OPEN ACCESS

Received: 8 July $2018 \quad$ Revised: 8 August 2018

Available Online: 20 October 2018

DOI: $10.5861 /$ ijrse. 2018.3018

Accepted: 30 August 2018

\title{
Abstract
}

The study aimed at examining the relationship between interventionist classroom management and learning of pupils with disabilities in primary schools. The objectives of the study were; (i) to examine the relationship between teacher proximity and learning of pupils with disabilities in primary schools, (ii) to analyze the relationship between relationship building and learning of pupils with disabilities in primary schools, and (iii) to examine the relationship between sitting arrangement and learning of pupils with disabilities in primary schools. A cross sectional survey research design was used to obtain information from 135 respondents. A questionnaire, interview guide and focus group discussion template were used as tools to collect data for the study. Quantitative and qualitative data collected was analyzed using the Statistical Package for Social Sciences (SPSS) and thematic content analysis respectively. Pearson product moment correlation coefficient results showed that a positive statistically significant relationship existed between teacher proximity and learning of pupils with disabilities $(r=.69, n=135, p<.01)$, a positive statistically significant relationship with relationship building $(r=.52, n=135, p<.01)$ and sitting arrangement $(r=.38, n=135, p$ $<.01)$. It was concluded that teacher proximity has the highest statistically significant effect with learning of pupils with disabilities. Relationship building has a moderate statistically significant effect on the learning of pupils with disabilities. Sitting arrangement has the least statistically significant effect with learning of pupils with disabilities. It is recommended that teacher proximity, relationship building and sitting arrange should be considered when using interventionist classroom management for better learning of the disabled pupils.

Keywords: interventionist classroom management; disabled children; inclusion; reframing 


\section{Interventionist classroom management and learning of children with disabilities in primary schools: An inclusive and reframing approach}

\section{Introduction}

Classroom management is defined as an art of designing and implementing strategies by a teacher towards setting up a conducive learning environment for pupils with and without disabilities (Korpershoek, Harms, De Boer, Van-Kuijk, \& Doolaard, 2016; Margareth, 2019). Interventionist classroom management comprise of actions a teacher takes to create a supportive environment for the academics, social and emotional development of pupils (Korpershoek, 2016). A teacher who cares about his/ her pupils transmits knowledge effectively and has a good interaction with them due to the creation of an emotional link and environment (Kabeera, 2019; Reis da Luz, 2015; Allen, Gregory, Mikami, Lun, Hamre, \& Pianta, 2013). Improving the quality of teacher-pupil interactions within a classroom depends upon a solid understanding of the nature of effective teaching for pupils in a school. Interventionist approach to classroom management plays a big role in the development of the directing learning process of pupils with disabilities (Udoba, 2014). Interventionist classroom management involves five types of actions to help a teacher to offer high quality classroom management; (a) teachers must be caring to learners, (b) develop supportive relationship with learners, (c) organize and implement instructions in ways that optimize pupils' access to learning, (d) teachers encouraging pupils' engagement in academic tasks, and (e) using of group management methods. This is also used in establishing rules and procedures a teacher uses to promote the development of pupils' social skills and self-regulation (Korpershoek et al., 2016; Kabeera, 2019). Disability is defined as a restriction or lack of ability to perform an activity by a pupil in a manner considered normal. Disability might be manifested in terms sensory, cognitive, intellectual, reading, writing and mathematical difficulties or impairments (Lipta \& Deba, 2015).

Learning of children with disabilities is the process through which a child with impairments such as mental, physical, social, cognitive and deafness acquire self-discipline, gains reading skills, counting skills, writing skills, retrieve information, comprehend information and make decisions while at school (Lamport, Lucheia \& Ward, 2012). It has been noted that effective teaching and learning cannot take place in a poorly managed classroom (Jones \& Jones, 2012). Educating pupils with disabilities in inclusive classrooms is an important objective of educational policies in many countries. Inclusion of pupils with disabilities is increasingly being promoted worldwide (Marloes, Pijl, Nakken, \& Houten, 2010; Nketsia, 2016). On a global scene teachers use various styles in managing their classrooms but little is known about the relationship between interventionist classroom management and learning of pupils with disabilities (Park \& Brannon, 2013). To achieve effective classroom management learners with disabilities have been included in normal classrooms (Chevon \& Corcoran, 2014). Reframing of students' behavior includes understanding and distinguishing students' behavior, rethinking, controlling and power dynamics, in a learning environment. It might also call for being proactive instead of reactive and responding to children rather than their behavior (Fawns \& Salder, 1996).

\subsection{Models of Classroom Management}

There are different models of classroom management that have emanated in teaching and learning. These have been as a result of the diversity of the pupils managed in classrooms today. What might be a good classroom management practice to one set of pupils might be an utter disaster for another set. The major models of classroom management in schools today include; interventionist classroom management, noninterventionist classroom management, and interactivist classroom management. Interventionist classroom management suggests that pupils' learning and development is a product of the learning environment as a result of the interventions in the learners' daily environment (Krause, Bochner, \& Duchesne, 2006; Malmgren, Trezek, \& Paul, 2005). Interventionist classroom management is a positive reinforcement in which rules are developed and 
enforced onto the learners in either a reward or consequence form (Krause, Bochner, \& Duchesne, 2006). Noninterventionist classroom management postulates that a pupil's potential for success is predetermined. In this process a teacher guides the learner to attain his/ her problem solving abilities, positive relationship and personal growth that ultimately can be executed independently in the absence of the teacher (Krause, Bochner, \& Duchesne, 2006). For the interactivist the learner's development is also a product of the environmental conditions guided by the pupils' daily environment. This can be seen in a positive reinforcement classroom in which rules are established and pupils are either rewarded or given consequences based on their adherence to these rules and regulations (Krause, Bochner, \& Duchesne, 2006).

\subsection{Interventionist Classroom Management}

According to Kayikc (2009) class room management refers to a process of arranging the classroom environment to satisfy the expectations of the educational system, curriculum, school, lesson, teacher and pupils. Interventionist classroom management constitutes of the rules, relationship patterns and administration of classroom. Interventionist classroom management by teachers regardless of the level of education entails interventions that include teachers' behavior focused interventions (Korpershoek et al., 2016). Both preventive and reactive interventions are included in this category and the most critical one is the pupils' socio-emotional development focused interventions (Korpershoek et al, 2016). In a school setting especially at the primary level teachers play a fundamental role in the cognitive and socio-emotional development of pupils by giving them an opportunity to learn. Effective classroom management sets a platform for learning and without it classrooms are disorganized and chaotic with little learning taking place (Korpershoek et al., 2016). The prior affirms that effective teaching and learning of pupils with disabilities goes with effective classroom management.

Classroom management is related to learning of pupils with disabilities in a way that if the teacher lacks the inclusive knowledge he or she faces challenges of poor classroom management (Chaula, 2014; Nketsia, 2016). Disabilities among pupils include but not limited to physical, intellectual, social, emotional and behavioral disabilities (Goodman \& Burton, 2010). In a learning setting for children with disabilities teacher proximity deals with how the teacher provides physical, mental, psychological and social assistance to pupils during learning processes. The purpose of proximity of a teacher can be to prevent pupils from disturbing each other (Rytivaara, 2012; Villamero \& Kamenopoulou, 2018). Teachers feel that life experiences, pro-active approaches and hands on work are important in the teaching of disabled learners in normal classrooms (Suc, Bokovec, Zveglic, \& Karpljuk, 2016). Interventionist classroom management considers different assessment strategies and how teachers employ them to respond to the needs of pupils with disabilities (Villamero \& Kamenopoulou, 2018). It has been noted that interventionist classroom management has been inadequately used by teachers for pupils with disabilities. This has led to a number of pupils with disabilities enter the education system unassessed, without classrooms and learning provisions (Mangope, Kuyini, \& Thenjiwe, 2012). O'Neill and Stephenson (2012) highlight that there is need to have teachers that have acquired special training on how to handle pupils with disabilities in a normal classroom setting.

Today, interventionist classroom management for pupils with disabilities is faced with challenges like high numbers of pupils in classrooms, limited number of teachers with skills to handle pupils with disabilities and lack of appropriate facilities among others (Kruijer, 2010). In schools, class sizes are too big for teachers to facilitate quality learning for disabled (Udoba, 2014, Barton, Irby, Tong, Torres, \& Sandlin, 2018). These have negatively affected the quality education and learning for pupils with disabilities. Classroom management among primary school is affected by several other factors that include pupil teacher ratios which are too high (Nakabugo et al., 2010). Effective teaching and learning cannot take place in poorly managed classrooms (Jones \& Jones, 2012). Effective interventionist classroom management strategies support quality teaching and learning which is based on the principle of a positive classroom environment (Korpershoek, 2016).

Effective interventionist classroom management strategies focus on preventive rather than reactive classroom management strategies among teachers in primary education. However, teachers frequently use 
Musa, M., \& Aidah, N.

reactive strategies such as punishing disruptive pupils (Shook, 2012; Kabeera, 2019). It is not clear whether these strategies effectively change pupils' behavior and this may be caused by lack of knowledge about the effectiveness of preventive strategies (Peters, 2012). Interventionist classroom management can make education a powerful tool in unifying pupils with disabilities and those without in a classroom setting (Mowat, 2010).

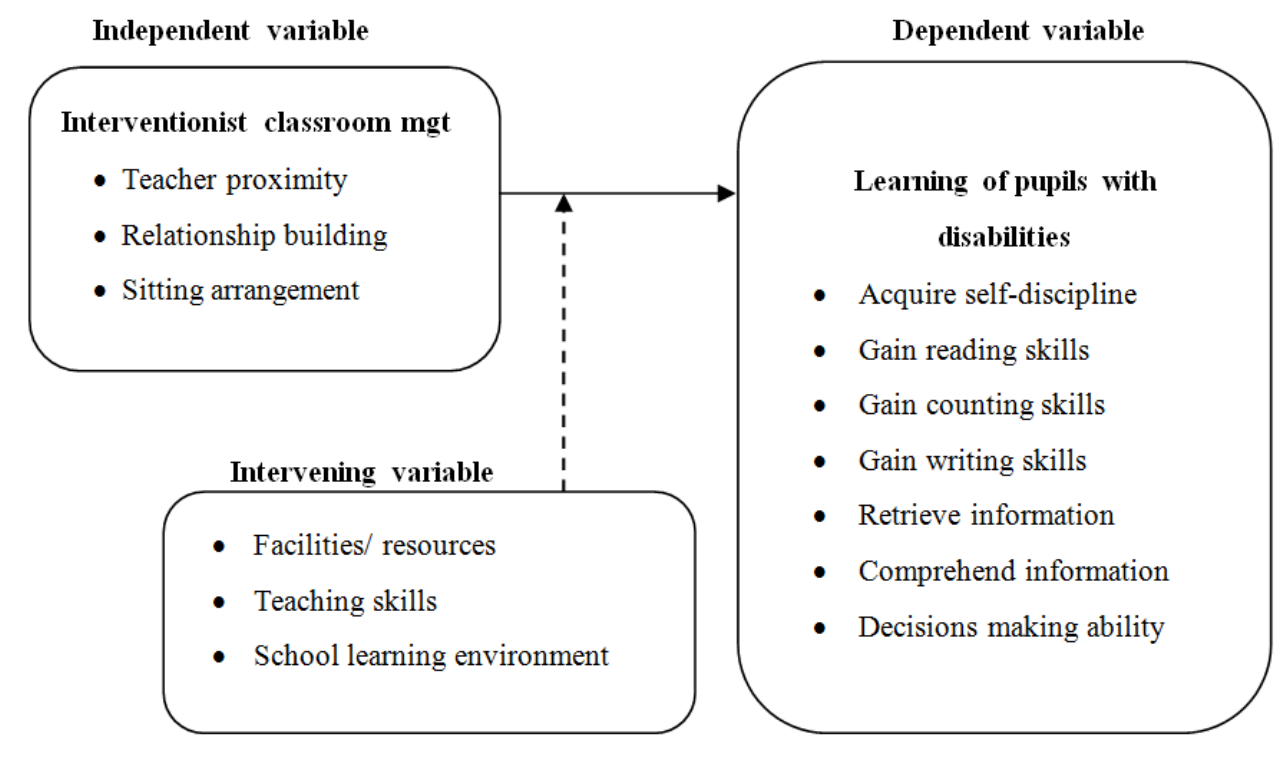

Figure 1. Classroom management and learning of pupils with disabilities

Figure 1 presents interventionist classroom management (teacher proximity, relationship building and sitting arrangement) as the independent variable and learning of pupils with disabilities as the dependent variable. The intervening variables include teaching skills, facilities/ resources and school learning environment. The above variables are hypothesized to play a role in the learning of pupils with disabilities.

\section{Theoretical Review}

According to Miller (2011) the social learning theory states that both cognitive and behavioral learning takes place through observation, modeling and imitation among others. The main characteristic of the social learning theory is the centrality of observational learning and a causal model that involves an environment - person behavior system with cognitive contributions, self-efficacy and agency being part of the chain (Miller, 2011). This presumes that academic and behavior modeling takes place through verbal instruction, symbolic modeling which occurs through attention, retention, reproduction and motivation. Advocates for inclusive learning highlight that actions help pupils with disabilities to be emerged into a learning community that mimics society environment (Nketsia, 2016).

Through social learning disabled pupils are able to interact with their normal peers and also develop friendship. When disabled pupils are included in the regular classrooms they have the opportunity to see their peers' working habits and they can model those habits and behaviors to reflect their own (Miller, 2011). With inclusive learning pupils with disabilities can learn from their peers without disabilities as well as with the support of their teachers to gain a better understanding of the concepts taught. In Uganda several laws and acts are in place to cater for the learning of children with disabilities. Such documents include; the Constitution of Republic of Uganda (1995), the persons with disability act (2006), national policy on disability in Uganda (2006), policy on special needs and inclusive education (2011), among others. According to Senkaaba (2014) policies on disabilities and inclusive education stipulate for the provision of specialized instructional materials, equipment and supportive services to disabled learners. He also articulated the need for training disabled learners and inclusive education personnel. Senkaaba also provided for guides on assessing the physical environment in schools, curriculum, and information for disabled children in schools. In Uganda, the persons with disability act 
Interventionist classroom management and learning of children with disabilities in primary schools

(2006) ratifies the United Nations Convention on the rights of persons with disabilities (2008). Both instruments demand for accessing equity and quality as regards educational services for persons with disabilities (Senkaaba, 2014).

\subsection{Learning of Pupils with Disabilities}

Teachers play a very important role in the learning process of pupils with disabilities. Pupils with disabilities idealize what teachers do and try to copy them, thus, learning (Rasheed, Humayon, \& Ahmed, 2016). A teacher for this matter needs to be motivated in order to be able to offer quality demonstrations to pupils in an inclusive classroom (Nketsia, 2016). Inclusion of pupils with disabilities in the normal classroom has brought about a challenges for teachers to handle large classrooms (Lamport, Lucheia, \& Ward, 2012; Nketsia, 2016). The challenges of teaching pupils with disabilities in normal classrooms is that normal classrooms have a combination of various children who consist of gifted, slow learners, mentally-retarded, hyperactive, emotionally challenged, and low socio-economic status pupils. These tend to learn at different rates and also need different attention. The notion of including disabled learners in regular classrooms has been emphasized recently by the different education stakeholders (Mangope, Kuyini, \& Thenjiwe, 2012). Therefore, it is vital that learners are assessed before entry into primary schools to ensure that schools are able to provide them with the necessary facilities and resources to support their learning (Kuyini \& Mangope, 2011). Pupils with mild disabilities can attend ordinary schools and participate in all school activities with the rest of the normal learners (Senkaaba, 2014).

There are special schools where learners with severe learning disabilities receive specialized learning. It is noted that there are instructional challenges in teaching disabled children in inclusive classrooms (Mtitu, 2014; Nketsia, 2016). The challenges include not having equipment, text and reference books and teaching in substandard classrooms with limited ventilation and scratched blackboards. In primary schools learning takes place through social interactions, being able to communicate easily and effectively with others which greatly supports acquiring knowledge and skills (Gainsley, 2013). A diverse combination of classroom management practices along with focusing on delivering differentiated instruction that targets each pupil individually in the classroom has made a regular education teacher's job beyond difficult (Lamport, Lucheia, \& Ward, 2012). In a study by Smith, Spooner, Jimenez, and Browder (2013) pupils with multiple severe disabilities learned science concepts through hands on experiments and time delay to train vocabulary. In addition, Courtade, Browder, Spooner and Dibiase (2010) demonstrated how teachers of pupils with severe disabilities could learn to teach an inquiry based science lesson with concomitant learning by the participating pupils.

Interventionist classroom management can offer great work in attaining education for all children including those with disabilities (Kawempe Division Education Report, 2015). Pupils with disabilities have differences in terms of disability and these require special care and treatment from teachers at the school. The primary schools' management have to advertise and recruit qualified teachers to offer teaching services to pupils with disabilities. The teaching services include; attending classes, arranging for their seats, building relationship, keeping close proximity with pupils, managing time effectively and carrying out preparations with the aim of achieving learning. Despite schools employing special and qualified teachers to teach disabled pupils, pupils with disabilities still face challenges with their learning that is reflected by inability to read, count, write, retrieve and comprehend taught information (Kawempe Division Education Report, 2015). This has also been observed in a way the disabled children are demoralized in attending classes as they think that the classes are not meant for them. Teaching of pupils with disabilities is done in inclusive classrooms but might have an effect on how the disabled children learn. It is hoped that improvement in classroom management of disabled children would improve their learning. Classroom management by teachers and learning of pupils with disabilities should be examined to improve the academic standards. If this is not done this will lead to more pupils with disabilities dropping out of school (Margareth, 2019), increase illiteracy among pupils with disabilities and eventually poor social status and development in the community. Interventionist classroom management in this study was based on three aspects that included teacher proximity, relationship building and sitting arrangement. This study sought 
Musa, M., \& Aidah, N.

to examine the relationship between interventionist classroom management and learning of children with disabilities in primary schools. The study addressed the following objectives:

$>\quad$ To examine the relationship between teacher proximity and learning of pupils with disabilities in primary schools.

$>\quad$ To analyze the relationship between relationship building and learning of pupils with disabilities in primary schools.

$>\quad$ To examine the relationship between sitting arrangement and learning of pupils with disabilities in primary schools.

\section{Methods}

The methods used in the study included research design, study population, sample size, sampling methods, data collection tools, quality controls and data analysis.

\subsection{Research Design}

The study employed a cross sectional survey designs with both quantitative and qualitative approaches to data collection and analyses. The design was adopted to examine the relationship between interventional classroom management (teacher proximity, relationship building and sitting arrangement) and learning of pupils with disabilities in primary schools.

\subsection{Population and Sample}

Kawempe Division has a population 11 government aided primary schools with a population of 60 teachers with the requisite skills to teach disabilities pupils in primary schools. All the government primary schools in Kawempe division have over 100 pupils with severe learning disabilities. From the population using census, simple random sampling and purposive sampling a sample of 3 head teachers, 52 classroom teachers and 80 pupils with disabilities were selected to participate in the study. Simple random sampling was used due to its ability to offer an equal chance of participants getting involved in the study, thus, minimizing/eliminating sampling errors and bias. Purposive sampling was chosen because the researcher needed students with particular characteristics; upper primary and had the ability to responding to the questions asked to them. The sample of the study was determined by Krejcie and Morgan (1970) sample determination table.

\section{Table 1}

Distribution of Study Respondents and Sampling Methods

\begin{tabular}{|c|c|c|c|c|}
\hline Category & & Population & Sample Size & Sampling Method \\
\hline Head teacher & & 3 & 3 & Census \\
\hline Teachers & & 60 & 52 & Simple random sampling \\
\hline Pupils with disability & & 100 & 80 & Purposive sampling \\
\hline & Total & 163 & 135 & \\
\hline
\end{tabular}

\subsection{Instruments}

A multifaceted approach to data collection was used to collect data for the study which included the use of questionnaires, interview guide and focus group discussions template. They were all used to collect the thick data for the study.

\subsection{Questionnaire, Interview Guide and Focus Group Discussion Guide}

The questionnaire was developed based on the four study variables; teacher proximity (8 items), relationship 
Interventionist classroom management and learning of children with disabilities in primary schools

building (11 items), sitting arrangement ( 9 items) and learning of students ( 7 items). This questionnaire was rated based on a five point Likert scale model; $1=$ strongly disagree, $2=$ disagree, $3=$ neither agree nor disagree, $4=$ agree and $5=$ strongly agree. The interview guide was used to collect information from the key informants who were the school head teacher. They were interviewed independently on a face to face basis. Focus group discussions were similar to interviews but respondents were interviewed in groups at different times. The focus group discussion guide was used as an instrument of data collection to collect data from respondents.

\subsection{Validity and Reliability}

From the results of content validity (.95) it was established that the instrument (questionnaire) had the required items to measure what it was supposed to measure. Also, the results of the Cronbach's alpha (.932) revealed that the instrument would produce consistent results when retested. Testing for both validity and reliability of the instrument used for data collection was done in a pilot study before collecting data for the final study.

\subsection{Data Analysis}

The collected data was edited, coded, classified and later analysed using Statistical Package for Social Scientists. Descriptive statistics were used to obtain frequencies and percentages for the narrow areas of analysis. Inferential statistics were used to determine the relationship and effect of the independent variables onto the dependent variable of the study.

\section{Results}

This section presents and analyses the findings of the study. Table 2 presents the characteristics of the respondents as regards their gender and age.

Table 2

Gender and Age of the Respondents

\begin{tabular}{llccc}
\hline \multicolumn{1}{c}{ Item(s) } & \multicolumn{1}{c}{ Categories } & Frequency & Percent \\
\hline Gender & Male & & 89 & 65.9 \\
& Female & & 46 & 34.1 \\
& & Total & 135 & 100.0 \\
\multirow{2}{*}{ Age } & Below 18 years & & 80 & 59.3 \\
& Above 18 years & & 55 & 40.7 \\
& & Total & 135 & 100.0 \\
\hline
\end{tabular}

According to the results of the characteristics of the respondents in Table 2, it is shown that $89(65.9 \%)$ of the respondents were males while 46(34.1\%) were female. Also, the age results in Table 2 highlight that 80(59.3\%) respondents were aged below 18 years while 55(40.7\%) were aged above 18 years. The results show that the respondents of the study were from a multi-diversified age groups.

Table 3

Sample of Pupils that Participated in the Study

\begin{tabular}{|c|c|c|c|}
\hline Item & Class of study Categories & Frequency & Percent \\
\hline \multirow[t]{4}{*}{ Class of study } & Primary Five & 6 & 7.5 \\
\hline & Primary Six & 31 & 38.8 \\
\hline & Primary Seven & 43 & 53.8 \\
\hline & Total & 80 & 100 \\
\hline
\end{tabular}

The results in Table 3 reveal that $6(7.5 \%)$ respondents (pupils) were in primary five class, 31(38.8\%) were in primary six class while $43(53.8 \%)$ were in primary seven class. In this study, the pupils with disability were selected purposively in upper primary classes because they had to answer questions which required relatively 
Musa, M., \& Aidah, N.

good self-presentation skills. Over 50 percent of the pupils who participated in the study were in the top most class (primary seven) of the primary section.

\section{Table 4}

Correlations between Teacher Proximity, Relationship Building, Sitting Arrangement \& Learning of Pupils

\begin{tabular}{lccc}
\hline & $\begin{array}{c}\text { Learning of pupils } \\
\text { Correlation coefficient }\end{array}$ & Sig (2-tailed) & $n$ \\
\hline Teacher proximity & .69 & $.004^{* * *}$ & 135 \\
Relationship building & .52 & $.009^{* *}$ & 135 \\
Sitting arrangement & .38 & $.008^{* *}$ & 135 \\
\hline
\end{tabular}

Note $p<05^{*}, p<.01$

According to the results in Table 4 it is observed that there is a relationship between teacher proximity and learning of pupils with disabilities $(r=.69, n=135, p<.01)$. The null hypothesis stated prior was rejected. From the same study it is observed that there is relationship between relationship building and learning of pupils with disabilities $(r=0.52, n=135, p<.01$ ). The null hypothesis that stated that there is no statistically significant relationship between relationship building and learning of pupils with disabilities was rejected. It was again noted that there is a statistically significant relationship between sitting arrangement and learning of pupils with disabilities $(r=0.38, n=135, p<.01)$. This implies that the null hypothesis stated prior to the study was rejected. This also means that sitting arrangement is related to learning of pupils with disabilities in a classroom setting.

Table 5

Regression for Teacher Proximity, Relationship Building, Sitting Arrangement and Learning of Pupils

\begin{tabular}{ccccccccc}
\hline \multirow{2}{*}{ Model } & $\mathrm{R}$ & R Square & \multirow{2}{*}{$\begin{array}{c}\text { Adjusted R } \\
\text { Square }\end{array}$} & $\begin{array}{c}\text { R Square } \\
\text { Change }\end{array}$ & F Change & df1 & df2 & $\begin{array}{c}\text { Sig. F } \\
\text { Change }\end{array}$ \\
\hline 2 & $.73^{\mathrm{a}}$ & .91 & .89 & .05 & 13.64 & 1 & 85 & $.006^{* * *}$ \\
3 & $.65^{\mathrm{b}}$ & .90 & .83 & .02 & 12.51 & 1 & 89 & $.001^{* * *}$ \\
4 & $.44^{\mathrm{c}}$ & .86 & .85 & .03 & 21.55 & 1 & 90 & $.007^{* *}$ \\
\hline Note. $p<.05^{*}, p<.01^{* * *}$ & & & & & & &
\end{tabular}

From the results of multiple regression in Table 5 teacher proximity as a statistical variable has a high effect with learning of pupils with disabilities $(r=.73 ; n=135, p<.01)$. This means that a unit increase in teacher proximity brings about $73 \%$ change in the learning of pupils with disabilities. The results presented on teacher proximity in the coefficients table (Table 5) represent $90 \%$ at the sample level while reflect $89 \%$ at the population level. Increased use of teacher proximity to disabled pupils during teaching and learning would bring a high increase in the learning of pupils with disabilities. According to the results of relationship building a positive moderate statistically significant relationship between relationship building and learning of pupils with disabilities is observed $(r=.65, n=135, p<.01)$. This implies that a unit increase in relationship building brings about $65 \%$ change in the learning of pupils with disabilities other factors kept constant. The results represent $90 \%$ at the sample level and $83 \%$ at the population level. Regression analysis results on siting arrangement highlight a low but statistically significant relationship between sitting arrangement and learning of pupils with disabilities $(r=.44, n=135, p<.01)$. This implies that a unit increase in sitting arrangement brings $44 \%$ change in the learning of pupils with disabilities other factors kept constant. The results represent $86 \%$ at the sample level and $85 \%$ at the population level. From the results of multiple regression it is noted that all the three variables under study (teacher proximity, relation building and sitting arrangement) have statistically significant effect on the dependent variable (learning of the students with disabilities).

\section{Discussion and Conclusions}

The results from the study highlight that teacher proximity has a statistically significant effect on learning of pupils with disabilities. The significant results are attributed to the fact that primary school teachers offer ample time to cater for pupils with disabilities. They use different teaching methods to enable the pupils with 
disabilities to learn. But the findings do not agree with literature by Deirdre (2010) who attested that excessive proximity by teachers caused disabled learners to become less involved in the learning process which negatively affected their learning. The results are also in agreement with McKeating (2013) who noted that teachers who looked at pupils on task made children with abnormal behaviors perform better. It was also noted that the level of proximity determines the degree of independence and social skills by a pupil in his or her learning process (Korpershoek et al., 2016; Villamero \& Kamenopoulou, 2018). In this study, excessive proximity practices by primary school teachers leads to increased chances that a child will learn more in a classroom setting. Pupils highlighted that:

“....teachers' presence stops them from disturbing other fellow pupils”. (P.7 pupils)

During the focus group discussions, it was expressed by one teacher that due to proximity punishments are given to pupils without disabilities who try to mistreat or discriminate against those with disabilities. She noted:

"When I am in class, I do punish pupils who imitate the lame pupils to act as an example to the
rest and this is intended to eliminate discrimination and promote learning among pupils with
disabilities..." (Teacher P.6 class)

During the interviews it was noted that all head teachers encouraged teachers to offer good time with pupils with disabilities. This was done by creating some time for interaction with the disabled learners. For example, one key informant noted:

“... For me I always encourage my teachers to keep close with pupils with disabilities because it helps them to know better these pupils and be able to take care of them where possible...." (Head teacher A)

The results of the study are in agreement with literature by Marloes et al. (2010), and Villamero and Kamenopoulou (2018) who asserted that interactions between pupils and teachers are added to the scheme of interactions between teachers and pupils. This is because research has shown that pupils with disabilities who have many interactions with their teachers perform better. Increased relationship building can lead to increased learning and potential among pupils with disabilities in primary schools. Relationship building is related to learning of pupils with disabilities and its increase makes more pupils with disabilities to be able to identify objects correctly, read, write/spell words correctly, count and comprehend information presented to them by the teachers (Rytivaara, 2012; Khudorenko, 2011).

The results are in agreement with Koster et al. (2009) who noted that primary school teachers should be able to make accurate assessments of pupils' social participation in order to notice problems in a timely manner. It should be noted that classmates are also important actors in interventions aimed at improving the social participation of pupils with disabilities (Pigga \& Merja, 2018). According to Chevon and Corcoran (2014) they revealed that a positive teacher-pupil relationship plays an established role in the developmental outcomes of pupils; positive teacher-pupils relationships may be particularly beneficial for pupils with disabilities. Carreno and Avila (2005) also stated that valued teacher-pupil relationships are seen to develop from a variety of processes including high achievement and pupils' engagement. From focus group discussions held with teachers it was expressed that teachers practiced relationship building among pupils with disabilities in different ways. One respondent noted that this is done by embracing pupils individually and calling them by names and respecting them the way they are. She asserted that:

“...... for me I practice relationship building by calling my pupils who have disabilities by their names and this makes them feel part of learning/ class....” (Teacher P.7 class)

Another teacher expressed that relationship building is practiced by carrying the pupil physically and interacting with them always. One male teacher in the focus group discussions asserted that: 
"We as teachers we are taught to be tolerant and this is applied to pupils with disabilities as well.... we offer them extra time to accomplish assignment or exams and this makes them to learn morelaim higher for better grades....” (Teacher P.7 class)

The results obtained under sitting arrangement are in agreement with literature by Huei (2009) who expressed that sitting arrangement and learning of pupils with disabilities in primary schools can be a dilemma due to pace of learning, space, learning styles and individual attention. In addition, Case-Smith and Holland (2009) argued that a classroom environment offers ideal circumstances for a child to develop his social skills and progress developmentally most especially for pupils with disabilities. Kuyini and Mangope (2011) revealed that learners should be assessed early on or upon entry into primary school to ensure that schools are able to provide them with the necessary services to support them in classroom learning. Ngware, Ciera, Musyoka, and Oketch (2013) noted that the policy implication to education is that pupils' sitting position can be manipulated in a way that it optimizes learning gains for slow learners. Proper sitting arrangement promotes disabled pupils' learning in terms of distance covered in class, space utilized and use of their facilities while learning. During the focus group discussions one respondent revealed that sitting arrangement has an effect to the learning of pupils with disabilities. He noted that this had occurred in terms of change of learning among pupils with disabilities. He noted that:

"My effort to make my pupils with disabilities learn they sit in front or near me. This makes them so active in class by responding to questions which is a sign of learning” (Teacher P.7 class)

Another teacher also noted that:

“........I make sure that pupils with disabilities sit in front to capture their attention and this helps me easily monitor them amidst other pupils without disabilities” (Teacher P.5 class)

The results are in agreement with Tagliacollo et al. (2010) who linked sitting arrangement to learning of pupils with disabilities in primary schools with sitting position becoming an important determinant of opportunity to learn.

\section{Conclusion and practical implications}

The findings of this study have implications to classroom management and learning of pupils with disabilities in primary schools. The results of this study have revealed that teacher proximity has highest effect on the learning of pupils with disabilities. Teacher proximity is the most significant predictor of learning among pupils with disabilities compared to other variables observed under this study. Relationship building had a moderate relationship with learning of pupils with disabilities. It had a moderate significant effect with learning of pupils with disabilities which is attributed to the fact that pupils share their thoughts and feelings with the teacher. Sitting arrangement in classrooms had a low statistically significant relationship with the learning of pupils with disabilities in primary schools. In the practical implication, teacher needs to consider teacher proximity as the most influencing aspect to the learning of pupils with disabilities during the teaching and learning process. This is followed with relationship building and sitting arrangement respectively.

Acknowledgement: This study was approved by the university (Islamic University in Uganda) Research Board before it was conducted.

\section{References}

Allen, J., Gregory, A., Mikami, A., Lun, J., Hamre, B., \& Pianta, R. (2013). Observations of effective teacher-pupil interactions in secondary school classrooms: Predicting pupil achievement with the classroom assessment scoring system secondary. School Psychology Review, 42(1), 76-98. 
Interventionist classroom management and learning of children with disabilities in primary schools

Barton, J., Irby, B. J., Tong, F., Torres, M., \& Sandlin, J. (2018). Secondary student achievement, particularly in science, related to school size, student socio-economic status, per pupil expenditures, student mobility rate, and percentage of non-white students: A modified best-evidence synthesis. International Journal of Research Studies in Education, 7(3), 1-17. https://doi.org/10.5861/ijrse.2017.1775

Case-Smith, J., \& Holland, T. (2009). Making decisions about service delivery in early child hood programs. Language, Speech and Hearing Services in Schools, 40(4), 416-423. https://doi.org/10.1044/0161-1461(2009/08-0023)

Chaula, G. J. (2014). Challenges that teachers face in implementation of inclusive education in primary schools in Tanzania: A case study of two primary schools in Tanzania [Unpublished Master's Dissertation]. Hedmark University College, Norway.

Chevon, L., \& Corcoran, T. (2014). Relationships with special needs pupils: Exploring primary teachers' descriptions. International Journal of Inclusive Education, 18(12), 1304-1320. https://doi.org/10.1080/13603116.2014.897385

Courtade, G., Browder, D. M., Spooner, F. H., \& Dibiase, W. (2010). Training teachers to use an inquiry-based task analysis to teach science to pupils with moderate and severe disabilities. Education and Training in Autism and Developmental Disabilities, 45(3), 378-399.

Deirdre, B. P. (2010). The inclusion of students with disabilities in mainstream post primary physical education from the perspective of the physical education teacher [Unpublished Master's Thesis]. Waterford Institute of Technology, Ireland.

Fawns, R., \& Salder, J. (1996). Managing students' learning in classrooms: Reframing classroom research. Research in Science Education, 26(2), 205-217. https://doi.org/10.1007/BF02356432

Gainsley, S. (2013). Building friendships in preschool. Curriculum Newsletter from High-Scope Foundation, 27(1), 1-18.

Goodman, R. L., \& Burton., D. M. (2010). The inclusion of pupils with BESD in mainstream schools: Teachers' experiences of and recommendations for creating a successful inclusive environment. Emotional and Behavioral Difficulties, 15(3), 223-237. https://doi.org/10.1080/13632752.2010.497662

Huei., L. W. (2009). Should all pupils with special educational needs (SEN) be included in mainstream education provision? A critical analysis. International Education Studies, 2(4), 154-161.

Jones, V. F., \& Jones, L. S. (2012). Comprehensive classroom management: Creating communities of support and solving problems $\left(11^{\text {th }}\right.$ ed). Upper Saddle River, New Jersey: Pearson.

Kabeera, P. (2019). Examining the influence of student's perception on mathematics performance: Case of three selected Rwandan secondary schools. International Journal of Research Studies in Education, 8(1), 33-41. https://doi.org/10.5861/ijrse.2018.3007

Kayikc, K. (2009). The effect of classroom management skills of elementary school teachers on undesirable discipline behaviour of pupils. Procedia - Social and Behavioral Sciences, 1(1), 1215-1225. https://doi.org/10.1016/j.sbspro.2009.01.218

Khudorenko, E. A. (2011). Problems of the education and inclusion of people with disabilities. Russian Education and Society, 53(12), 82-91. https://doi.org/10.2753/RES1060-9393531205

Korpershoek, H., Harms, T., De Boer, H., Van Kuijk, M., \& Doolaard, S. (2016). A meta-analysis of the effects of classroom management strategies and classroom management programs on students' academic, behavioral, emotional, and motivational outcomes. Review of Educational Research, 86(3), 643-680. https://doi.org/10.3102/0034654315626799

Krause, K., Bochner, S., \& Duchesne, S. (2006). Managing behavior and classrooms. Education psychology for learning and teaching ( $2^{\text {nd }}$ ed.). Melbourne, AU: Thomson Learning.

Krejcie, R. V., \& Morgan, D. W. (1970). Determining sample size for research. Educational and Psychological Measurement, 30, 607-610. https://doi.org/10.1177/001316447003000308

Kruijer, H. (2010). Learning how to teach: The upgrading of unqualified primary teachers in sub-Saharan Africa: Lessons from Tanzania, Malawi and Nigeria. Belgium Education International. Retrieved from https://issuu.com/educationinternational/docs/ei-research_learning-how-to-teach

Kuyini, A. B., \& Mangope, B. (2011). Student teachers' attitudes and concerns about inclusive education in 
Musa, M., \& Aidah, N.

Ghana and Botswana. International Journal of Whole schooling, 7(1), 20-37.

Lamport, A. M., Lucheia, G., \& Ward., A. (2012). Special needs pupils in inclusive classrooms: The impact of social interaction on educational outcomes for learners with emotional and behavioral disabilities: Liberty University (Virginia). European Journal of Business and Social Sciences, 1(5), 54-69.

Lipta, S. R., \& Deba, S. (2015). Including children with special needs: Upper Primary Stage. National Council of Educational Research and Training.

Malmgren, K. W., Trezek, B. J., \& Paul, P. V. (2005). Models of classroom management as applied to the secondary classroom: The clearing house. A Journal of Educational Strategies, Issues, and Ideas, 79(1), 36-39. https://doi.org/10.3200/TCHS.79.1.36-39

Mangope, B, Kuyini, A. B., \& Thenjiwe, M. (2012). Assessment of learners with special needs for inclusive education in Botswana: Issues and challenges for schools. Department of Educational Foundations, Faculty of Education, University of Botswana.

Margareth, G. A. (2019). Gender differences in academic achievement: A matter of contextual classroom influence? International Journal of Research Studies in Education, 8(1), 1-20. https://doi.org/10.5861/ijrse.2018.2013

Marloes, K., Pijl, S. J., Nakken, H., \& Houten, E. V. (2010). Social participation of pupils with special needs in regular primary education in the Netherlands. International Journal of Disability, Development and Education 52(1), 59-75. https://doi.org/10.1080/10349120903537905

McKeating, E. (2013). Including children with ASD regular kindergarten and first grade classroom: Teacher attitude, child progress and classroom quality [npublished PhD Dissertation].niversity of Pittsburgh, Pittsburgh.

Miller, P. H. (2011). Theories of developmental psychology (5th ed). New York, USA: Worth Publishers.

Mowat, J. (2010). Inclusion of pupils perceived as experiencing social and emotional behavioral difficulties (SEBD): Affordances and constraints. International Journal of Inclusive Education, 14(6), 631-648. https://doi.org/10.1080/13603110802626599

Mtitu, E. A. (2014). Learner centred teaching in Tanzania: Geography teachers' perceptions and experiences [Unpublished PhD Thesis]. Victoria University of Wellington, Wellington, New Zealand.

Nakabugo, M. G., Opolot-Ukurut, C., Ssebunga, C. M., Ngobi, D. H., Maani, J. S., Gumisiriza, E. L., Mbaga, R., Alupo, C., Byamugisha, A., Bisikwa, R., Tukesiga, J., Ndawula, R., \& Bbosa, D. (2010). Instructional strategies for large classes: Baseline literature and empirical study of primary school teachers in Uganda. Makerere University, Kampala. Retrieved from https://home.hiroshima-u.ac.jp/cice/wp-content/uploads/publications/report2/AA/Kampala_Uganda.pdf

Ngware, M. W., Ciera, J., Musyoka, P. K., \& Oketch, M. (2013). The influence of classroom seating position on student learning gains in primary schools in Kenya. Creative Education, 4(11), 705-712. https://doi.org/10.4236/ce.2013.411100

Nketsia, W. (2016). A cross-sectional study of pre-service teachers' views about disability and attitudes towards inclusive education. International Journal of Research Studies in Education, 6(3), 53-68. https://doi.org/10.5861/ijrse.2016.1610

O’Neill, S., \& Stephenson, J. (2012). Does classroom management influence pre-service teachers' perceived preparedness or confidence? Teaching and Teacher Education, 28(8), 1131-1143. https://doi.org/10.1016/j.tate.2012.06.008

Park, J., \& Brannon, E. M. (2013). Training the approximate number system improves math proficiency. Psychological Science, 20(10), 1-7. https://doi.org/10.1177/0956797613482944

Peters, J. H. (2012). Are they ready? Final year pre-service teachers' learning about managing pupil behaviour. Australian Journal of Teacher Education, 37(9), 18-42. https://doi.org/10.14221/ajte.2012v37n9.2

Pigga, K., \& Merja, P. (2018). Pupils' primary school achievements in Northern Finland. International Journal of Research Studies in Education, 7(2), 25-39. https://doi.org/10.5861/ijrse.2017.1654

Rasheed, M. I., Humayon, A. A., \& Ahmed, U. A. A. (2016). Factors affecting teachers' motivation. International Journal of Educational Management, 30(1), 101-114. https://doi.org/10.1108/IJEM-04-2014-0057 
Interventionist classroom management and learning of children with disabilities in primary schools

Reis da Luz, F. S. (2015). The relationship between teachers and pupils in the classroom: Communicative language teaching approach and cooperative learning strategy to improve learning [Unpublished Master's Thesis]. Bridgewater State University, Massachusetts, USA.

Rytivaara, A. (2012). Towards inclusion and teacher learning in co-teaching. University Library of Jyvaskyla, University of Jyvaskyla.

Senkaaba, S. (2014). Special needs and inclusive education policy in offing. Kampala Uganda New Vision Printing.

Shook, A. C. (2012). A study of pre-service educators' dispositions to change behavior management strategies: Preventing school failure. Alternative Education for Children and Youth, 56(2), 129-136. https://doi.org/10.1080/1045988X.2011.606440

Smith, B. R., Spooner, F., Jimenez, B. A., \& Browder, D. (2013). Using an early science curriculum to teach science vocabulary and concepts to pupils with severe developmental disabilities. Education \& Treatment of Children, 36(1), 1-31. https://doi.org/10.1353/etc.2013.0002

Suc, L., Bokovec, B., Zveglic, M., \& Karpljuk, D. (2016). Primary school teachers' attitudes towards inclusive education in Slovenia: A qualitative exploration. Journal of Universal Excellence, 5(1), 30-46.

Tagliacollo, V. A., Volpato, G. L., \& Pereira Jr., A. (2010). Association of pupil position in classroom and school performance. Educational Research, 1(6), 198-201.

Udoba, H. A. (2014). Challenges faced by teachers when teaching learners with developmental disability [Unpublished Master's Thesis]. University of Oslo, Oslo, USA.

Villamero, R. J. C., \& Kamenopoulou, L. (2018). Teachers' assessment strategies for children with disabilities: A constructivist study in mainstream primary schools in Negros oriental, Philippines. In L. Kamenopoulou (Ed.), Inclusive education and disability in the global south (pp. 81-107). Palgrave Macmillan. https://doi.org/10.1007/978-3-319-72829-2_4 
Musa, M., \& Aidah, N. 